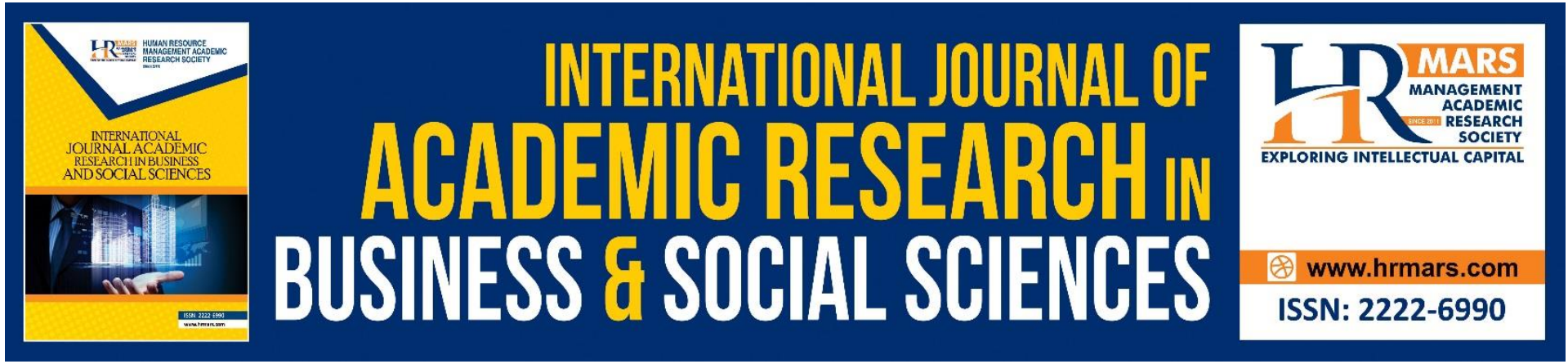

\title{
The Influence of Critical Success Factors (CSF) Of Entrepreneurial Practices on Business Performance among Entrepreneurs in The Petaling District Mosques, Selangor
}

Nurul Aini Ilmiah Munzir \& Nurul Fadly Habidin

To Link this Article: http://dx.doi.org/10.6007/IJARBSS/v11-i8/10742

DOI:10.6007/IJARBSS/v11-i8/10742

Received: 07 June 2021, Revised: 11 July 2021, Accepted: 28 July 2021

Published Online: 09 August 2021

In-Text Citation: (Munzir \& Habidin, 2021)

To Cite this Article: Munzir, N. A. I., \& Habidin, N. F. (2021). The Influence of Critical Success Factors (CSF) Of Entrepreneurial Practices on Business Performance among Entrepreneurs in The Petaling District Mosques, Selangor. International Journal of Academic Research in Business and Social Sciences, 11(8), 437-455.

\section{Copyright: (c) 2021 The Author(s)}

Published by Human Resource Management Academic Research Society (www.hrmars.com)

This article is published under the Creative Commons Attribution (CC BY 4.0) license. Anyone may reproduce, distribute, translate and create derivative works of this article (for both commercial and non-commercial purposes), subject to full attribution to the original publication and authors. The full terms of this license may be seen at: http://creativecommons.org/licences/by/4.0/legalcode

Vol. 11, No. 8, 2021, Pg. 437 - 455

Full Terms \& Conditions of access and use can be found at http://hrmars.com/index.php/pages/detail/publication-ethics 


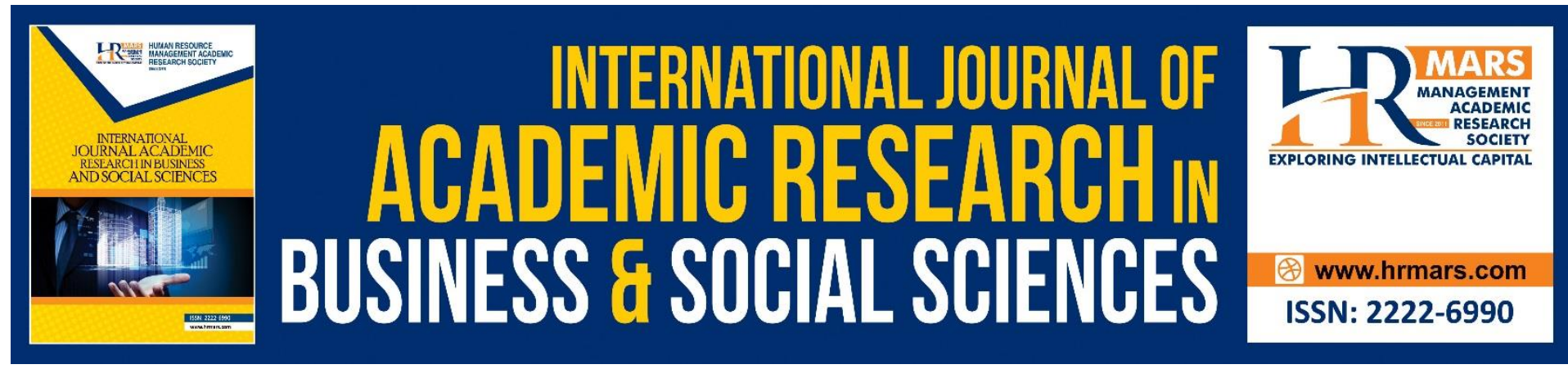

\title{
The Influence of Critical Success Factors (CSF) Of Entrepreneurial Practices on Business Performance among Entrepreneurs in The Petaling District Mosques, Selangor
}

\author{
Nurul Aini Ilmiah Munzir \& Nurul Fadly Habidin \\ Faculty of Management and Economic, Universiti Pendidikan Sultan Idris, 35900 Tanjung \\ Malim, Perak, Malaysia
}

\begin{abstract}
The aim of this research is to achieve three prime objectives that are:- identifying the stage of entrepreneurship practice critical success factors among the entrepreneurs running some business at the mosques in Petaling District of Selangor, establishing the link between entrepreneurship practice critical success factors with their business performance at the mosques in Petaling District of Selangor and studying the entrepreneurship practice critical success factors influencing their business performance at the mosques in Petaling District of Selangor. Thus, quantitative research design has been opted to justify the research scope and 18 hypotheses. The quantitative method through observation techniques and survey were distributed to 70 selected samples out of 86 available business units. Descriptive analyses indicates the average value and standard gap that rank the top, initiates teamwork factors that obtain the average value 4.2667. The correlation finding, on the other hand, illustrates that marketing management, strategic planning, ICT skill, communication network, training and education as well as entrepreneurship orientation note significant link with the business performance while financial management and teamwork implies to extreme unfavourable significant link. The finding of multiple regression analyses, however, displays three critical success factors influencing the business performance, namely:- strategic planning, training and education and also entrepreneurship orientation. The research implication demonstrates several proposals that substantially caters for certain parties' essentials, particularly the mosques' authority committee that need to enhance the activity of business errands with potentially maximum business opportunities offered to the whole community.
\end{abstract}

Keywords: Critical Success Factors, Entrepreneurial Practices, Business Performance.

\section{Introduction}

The history of entrepreneurship has started actively over the past 300 years that involve trading between the continents as such China, India, Asia, and the Mediterranean. The Silk Road has been a catalyst to the great development among the world's major civilizations such as Rome, Persia, India, China, and Egypt. One of the earliest proponents that support the idea was Adam Smith who has been describing the market in his writing since early on. 
Entrepreneurship then kept on growing rapidly until there was a sudden change and the advent of a new era in the field of information and communication technology (Rahim et al., 2017). Yusof (2010), reckons that by the $21^{\text {st }}$ century, the entrepreneurial scenario will challenge the ability of entrepreneurs in managing their business, such as the challenge of managing proactive and competitive workforces.

Per the Islamic perspective, entrepreneurship is seen as a major manifestation of a profession or occupation. A Muslim is very much encouraged to actively and continuously engage in any entrepreneurial activities (Abdullah et al., 2015). In Malaysia particularly, many job opportunities especially in the business field were being created for the community so that they can take part in the country's economic development. Nasharudin and Harun (2010) stated that the government encourages the community to take the opportunity in business and become entrepreneurs so that they can support themselves and their families. The spirit of wanting to operate a business and entrepreneurial activities can be instilled and nurtured in every layer of society (Basir et al., 2009). One of many places that stand out in the community to operate their business is the mosque area. Mat Desa and Sarif, (2013) suggest that mosques play a very important role in the economic development of Muslims today as such in reviving the Islamic environment through business activities. Among other functions of the mosque is as a place to preach or carry out 'dawah' that provide Islamic understanding to the vast community, as a community service center and a welfare center for the neglected community. The mosque is not only a place for Muslims to perform special acts of worship such as prayer, the Qur'an recitation, I'tikaf, and the like but also a place to perform general acts of worship such as imparting and seeking knowledge, having a discussion, exchanging opinions, planning and implementing various activities to develop the ummah from various aspects including being one of the catalyst institutions towards the economic generation of the ummah today (Aris \& Musa, 2014). This is due to the strategic position of the mosque which is an area that is in the focus of the community as a contributor to prosperity and a symbol of strength and unity among the Muslim community (Mohammat, 2009).

Critical Success Factors (CSF) is the most important element to achieve a competitive advantage for firms in the existing industry. Based on the CSF, an organization can see whether its business performance has succeeded or failed in achieving the vision and mission that was created before the organization was formed (Manaf et al., 2012). According to Gates (2010), critical success factors were introduced by John F. Rockart in 1979 as a way to help senior executives determine their very much needed information to manage their organizations. Rockart also found that CSF was very much in line with the concept of 'success factors' that was introduced by (Daniel, 1961).

The statement was also supported by Johnson (2013), who expressed Daniel's view that there are usually three to six factors that control the success of an organization in an industrial sector. In addition, Rockart also defines the concept of CSF in management thus further suggests that it can be measured and was directly related to the organizational achievement and competitive performance in the organization itself. There are two types of factors that influence the success of entrepreneurs, namely internal factors and external factors. Internal factors include factors of entrepreneurial characteristics and entrepreneurial orientation as well as adherence to religion while external factors include factors in the business organizations. Among them are management skills, experiences in both management and the industry, economic conditions and planning, social relations, network, and marketing as well as government assistance and support (Nadzri et al., 2014). 
The success of a business will affects the performance of a business, whether it is declining, increasing, or in stable performance. Husen et al (2010) argue that the concept of business performance is related to the ongoing activities of an enterprise. Excellent and continuous performance is seen through a good and developed enterprise and can be created by having a competitive advantage through value creation. Entrepreneurs should also set the goals to be achieved in their respective businesses as their benchmark in determining the performance of business development. Three intermediate mediums are being used to measure the performance of goal achievement for entrepreneurs as such efforts in selling, adopting products to consumer needs, and sales planning (Mohamad, 2014).

In this study, researchers focus on both types of factors that influence business success, namely internal factors are seen through entrepreneurial orientation factors while external factors are seen through financial management factor, strategic planning factor, ICT skills factor, communication factor, teamwork factor, network factor, training and education factors, and entrepreneurial orientation factor.

\section{Problem Statement}

In this study, researchers have noted several issues related to business such as lack of exposure to knowledge in regards to business and entrepreneurship. Local entrepreneurs are also weak in accounting and financial management, they also do not have any established network or communications among other fellow entrepreneurs, not able to manage their business well, such as failed in providing training programs to improve employee skills and are not sensitive to location which is suitable or strategic to conduct their business (Tunggak et al., 2011). This is also supported by Lope \& Elias (2004) who found that among the weaknesses of entrepreneurs in managing their business are lack of capital, lack of marketing skills, lack of skilled workers, lack of knowledge in business and technology, lack of skills and inability to obtain suitable business premises.

Therefore, researchers will identify critical success factors for entrepreneurial practices that can improve the business performance of small entrepreneurs in mosque areas. The mosque was chosen as the target location for this study because this institution is seen to have less of a role in the eyes of the community. The task and responsibility to restore the role of the mosque as in the time of the Prophet Muhammad PBUH is a big challenge in today's globalized world. The function of the mosque is getting smaller and smaller after the fall of Islamic culture when the community only considers the mosque as a place to perform prayers and worship activities only. The role of the mosque needs to be expanded to keep pace with the ever-changing world and fast pace of the times and at least 50 roles are classified into three major categories, namely as a center of worship, as an education center, and a center for social activities (Yusoff, \& Sulaiman, 2004). Business is one of the social activities that play an important role that will bring changes in the roles of the mosque in this time. During the time of the companions of Prophet Muhammad PBUH, business was the main source in expanding the Islamic economy (Ghani, \& Sarif, 2005). Additionally, the factor of obtaining a daily supply of resources that are halal and pure from anything that is prohibited by Islamic law is highly questionable, and even among Muslims themselves, some people are still ignorant of the issue. This subject is being put forward in this study as to help increase public awareness on halal issues. The fact is that even in this advanced technology world, many people in the Muslim community only know part of the halal status information of goods and services sold in the market. There are still many sources of food, goods, and services in the market in which halal status is unknown or questionable. Consumers are more 
than producers. For that reason, for the Muslims, it is considered as 'fardhu kifayat' or an obligation to produce and distribute food, goods, and utensils, and services, as to guarantee the halal status is following the Islamic law (Jabatan Kemajuan Islam Malaysia Sabah, 2020).

From problems and issues that arose, the researcher had chosen businesses located in the mosque area as the target of the study. This is because a business that is located in a good area is guaranteed of its halal status and purity. To narrow down the area of the study, the researcher had chosen Petaling District, Selangor as the location to conduct the study on entrepreneurs who are active in doing business in the mosque area. The researcher has come to this decision because in the early reading and researching for information, it was found that there is still a lack of studies conducted that focuses on business entrepreneurs in the mosque area either in the country or in foreign countries. The mosque in Petaling District, Selangor was chosen as the study location because based on a report by Utusan Malaysia (2014), it was found that Masjid As-Salam Puchong Perdana was crowned as the Champion of Masjid Kariah in 2014 in the Malaysian Mosque Award which was held for the first time. Among the success factors of this mosque is their actively deliver dawah and making the mosque as a center for welfare and economic activities. Based on the survey and the result of interviews between the researcher and the coordinator of the Petaling District Mosque, it was found that mosques in this district are very active in economic activities through the opening of business sites, providing premises to entrepreneur, and allowing small entrepreneurs to open a bazaar business on Friday.

\section{Research Objectives}

The general objective is that the researcher wants to identify the critical success factors (CSF) that are significantly related to business performance among sellers in mosques at Petaling District, Selangor. Meanwhile, specific objectives are as follow:

1. To identify the level of critical success factors (CSF) for entrepreneurial practices among entrepreneurs who operate their business in the Petaling District mosques, Selangor.

2. To study the correlation or relationship between each critical success factor (CSF) with the business performance of entrepreneurs in the Petaling District mosques, Selangor.

3. To study the critical success factors (CSF) that influence the business performance of entrepreneurs in the Petaling District mosques, Selangor.

\section{Research Hypotheses}

Ha1: There is a significant relationship between financial management factors and the business performance of entrepreneurs in the Petaling District mosques, Selangor.

$\mathrm{Ha} 2$ : There is a significant relationship between marketing management factors and the business performance of entrepreneurs in the Petaling District mosques, Selangor.

Ha3: There is a significant relationship between strategic planning factors and the business performance of entrepreneurs in the Petaling District mosques, Selangor.

Ha4: There is a significant relationship between the ICT skill factors and the business performance of entrepreneurs in the Petaling District mosques, Selangor.

Ha5: There is a significant relationship between communication factors and the business performance of entrepreneurs in the Petaling District mosques, Selangor.

Ha6: There is a significant relationship between the teamwork factors and the business performance of entrepreneurs in the Petaling District mosques, Selangor. 
Ha7: There is a significant relationship between network factors and the business performance of entrepreneurs in the Petaling District mosques, Selangor.

Ha8: There is a significant relationship between training and education factors with the business performance of entrepreneurs in the Petaling District mosques, Selangor.

Ha9: There is a significant relationship between entrepreneurial orientation factors and the business performance of entrepreneurs in the Petaling District mosques, Selangor.

Ha10: The financial management factor affects the business performance of entrepreneurs in the Petaling District mosques, Selangor.

Ha11: Marketing management factor influence the business performance of entrepreneurs in the Petaling District mosques, Selangor.

Ha12: Strategic planning factor affect the business performance of entrepreneurs in the Petaling District mosques, Selangor.

Ha13: The ICT skills factor affects the business performance of entrepreneurs in the Petaling District mosques, Selangor.

Ha14: The communication factor affects the business performance of entrepreneurs in the Petaling District mosques, Selangor.

Ha15: The teamwork factor influence the business performance of entrepreneurs in the Petaling District mosques, Selangor.

Ha16: The network factor affects the business performance of entrepreneurs in the Petaling District mosques, Selangor.

Ha17: Training and education factors influence the business performance of entrepreneurs in the Petaling District mosques, Selangor.

Ha18: The Entrepreneurial orientation factor influence the business performance of entrepreneurs in the Petaling District mosques, Selangor.

\section{Conceptual Framework}

Figure 1 below is a conceptual framework model for the Relationship between Success Critical Factors with Business Performance. The model was adapted and edited from the study proposed by Abdul Talib et al (2013). 


\section{Critical Success Faktor (CSF)}

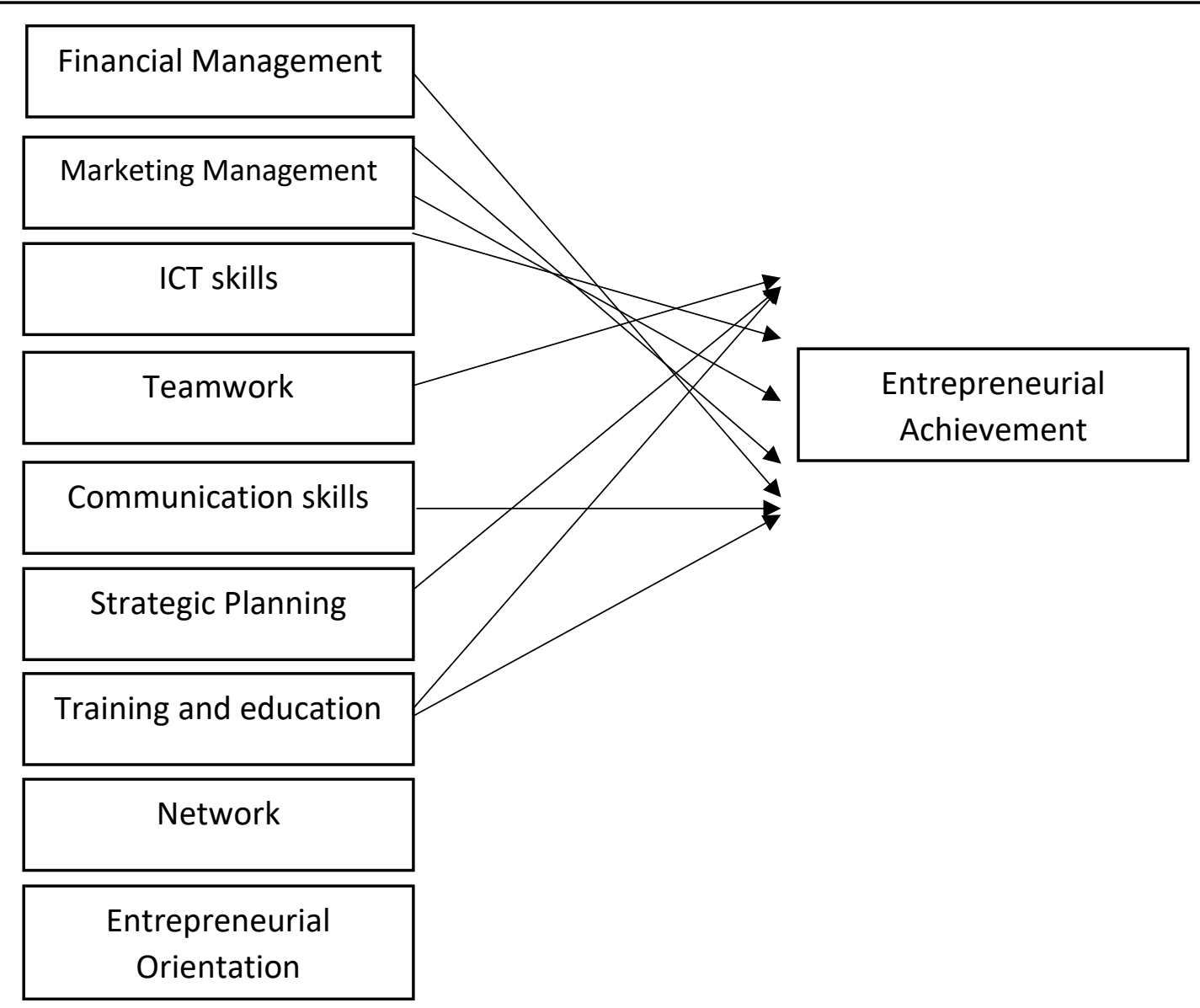

Figure 1: Conceptual Framework of the Study.

\section{Literature Studies}

i. The relationship between financial management factors and business performance. The financial management factor is one of the entrepreneurial practices that are highly emphasized in starting a business. Financial capability is proven to be one of the determinants of success and sustainability in a business. Profit and loss statement is a very important aspect of a financial management. This is because based on this statement, business performance will be evaluated based on their total sales and expenses in a particular period and a comparison of loss and profit can also be made between two particular periods based on this statement (Ali \& Mahat, 2009). Studies by Osman (2014); Mohamad (2006) further suggested that there is a relationship between financial management factors and business performance.

ii. The relationship between market management factors and business performance. Marketing management factors are very important in a business. Entrepreneurs have to be able to grasp and manage their marketing strategies to effectively increase their business profitability and performance. Additionally, entrepreneurs also need to be wise and smarter to seek and seize opportunities available to market their products. By identifying their competitors and provide the best promotions about products or services offered, a business will be able to attract more customers. And with a careless action or without taking into consideration of any marketing strategy, entrepreneurs will face greater risks of losing 
customers and may even suffer losses in their financial (Rajuddin \& Mohamad, 2008). A study by Nasir (2014), shows that marketing management factors have a positive relationship with business performance.

iii. The relationship between strategic planning factors and business performance.

Strategic planning has a very broad meaning where it cannot be explained in just a few simple words. Aside from that, it is also a process that involves several steps which had to be carefully implemented and in sequence order. The strategic planning process involves three main important components namely, environmental analysis, the formation of strategies and action programs, and control. Thus, to achieve long-term goals and evaluating business performances, entrepreneurs need to take into account these three components to improve the quality of the business (Mat \& Mohd, 2015). According to Wahab, Idris, and Abdul (2020), many studies had proven the existence of a significant relationship between strategic planning and business performance. However, the finding was interpreted through different approaches and against different responses. Empirical research in strategic planning focuses on two aspects which are the impact of strategic planning on firm performance and a strategic role in making strategic decisions. A study by Harom (2014), shows that there is a relationship between strategic management and small business performance.

iv. The relationship of ICT skill factor with business performance.

Through ICT, businesses have become increasingly competitive in recent years, new markets are available, and new job opportunities are being generated. Findings by Ab Wahab and Ahmad (2017), show that there are three factors in the use of ICT. The three factors include technology factors, organizational factors, and external factors. These three factors are significantly related to the business performance of SMEs in Malaysia. In accordance to Omar et al (2017), a person or an individual with quality products or services can trigger an extraordinary phenomenon through the use of information technology by sharing it on their social media.

v. The relationship between communication factor and business performance.

The results of Quan and Peter's (2015) study show that entrepreneurs in rural areas of Vietnam are friendlier towards their customers and this has become one of their success factors in doing business aside from providing good products at a very affordable price. This has caused their business to thrive and achieve a good performance.

vi. The relationship between the teamwork factor and business performance.

Teamwork advantages can be seen through the combination of knowledge, skills, ideas, and beliefs of all team members in carrying out their responsibilities towards achieving goals, which indirectly can improve the performance of each member in the organization, thereby also help to increase the organizational profits (Mad \& Nor, 2017). Meanwhile, the study by Delarue, Hootegem, Procter, and Burridge (2008) shows that there is a positive relationship between teamwork and organizational achievement. Oorganizational performance can be achieved through the behavior and attitudes of each employee who show good changes over time in addition to a pleasant environment. 
vii. The relationship between the network factor and business performance.

A business can establish its relationships with various businesses and organizations as it can directly or indirectly influence the performance of the business (Farinda, Kamarulzaman, Abdullah, \& Ahmad, 2009). An entrepreneur needs to create and establish a good social network between employers and employees, suppliers, and even competitors themselves. This is because the success of entrepreneurs can highly be influenced by their ability to identify the business environment through the process of exchanging relationships within their social networks (Hamed, 2006). Several studies show the hypotheses constructed are acceptable i.e such as the study by Ramli, Mohd and Ahmad, (n.d) which shows that business relationships have a positive relationship, are moderate in nature and have a significant influence on the performance of warehouse operations. This is because they believed that a good business relationship can bring a positive impact on the organization's finance.

viii. The relationship between training and education factors and business performance. Undeniably, training and education factors are also very important in running a business. Nawang (2012) found that education and training factors have a positive and significant relationship with business performance. If the level of education and training were below a good level, which is a moderate level or even below the moderate level, it may hinder the development of ideas, creativity, and innovations of entrepreneurs in the business world. Idris and Shahadan (2009) also suggested that training and courses are very important because entrepreneurs who are exposed to training and attend related courses to business operations such as food packaging, entrepreneurship, information technology, and financial management have a higher level of quality management than those who do not attend a related course or training.

ix. The relationship between the entrepreneurial orientation factor and business performance.

Based on the presented entrepreneurial theories, the entrepreneurial orientation leads to all the approaches found in the theory, namely the psychological approach which was seen based on characteristics of entrepreneurs such as risk-taking, proactive, innovation, confidence, courage, and tend to venture into business to reach a level of successfulness in the business itself. All approaches in the theory of entrepreneurship are in line with the entrepreneurial orientation factor that is to achieve business goals and improve performance in terms of profitability and customer satisfaction. Therefore, the Islamic approach in entrepreneurship was suggested as one of the ways to strengthen faith, especially to form a certain way of thinking among young entrepreneurs that tend to look and follow western influencers as their idol or figure in business (Hunter, 2014). Two studies proposed by Ahmad and Abdul (2013); Yogeswaran (2015) showed that the relationship between entrepreneurial orientation strategy and business performance is inconsistent. However, the independent variables such as innovation, proactive, and risk-taking show a significantly positive relationship with business performance.

\section{Research Methodology}

The researcher had opted to use a quantitative approach through the sampling method. A set of questionnaires was distributed to 70 businesses from a sample of 86 study populations. This set of questionnaires has a total of 85 items which had been divided into four sections. Section A contains seven items related to entrepreneurial personal information. Seven items 
in Section B are related to business information. 59 items in Section C related to critical success factors. Lastly, Section D contains 12 items related to business performance. The data collected were then analyzed using SPSS version 23 software to test all 18 hypotheses that were proposed and answer three research questions.

\section{Research Findings}

This chapter is divided into four sections. The first displays the demographic frequency analysis of respondents, the second part displays the mean and standard variation for the level of critical success factors of entrepreneurial practice, and the third part will then presents the finding of the relationship between the critical success factors of entrepreneurial practice and business performance. Lastly, the fourth part shows the finding of the analysis multiple regression to see the factors that mostly influence business performance.

Table 1 displays the demographic analysis of respondents who operate their business in the mosque area. The finding shows that the majority of respondents were men in the age range of 41 to 50 years old and all respondents were Malay. 85.7 percent already married and 82.9 percent had worked before starting a business. Education level is at a satisfactory rate which is at SPM and degree level with 35.7 percent. The highest percentage of respondents to start a business at the age of 41 to 50 years old with 42.9 percent and 65.7 percent of the business started operating in 2016. Sole proprietorship businesses are the highest at 87.1 percent and 95.7 percent of the business have one to three employees. 70 percent of businesses start a business with personal capital and earn a net business income of around RM 1,000 to RM 2,500 per month. Overall, the majority of businesses operated in the mosque area are Friday bazaars, which is at 74.3 percent. 
Table 1: Demographic Analysis of Respondents

\begin{tabular}{|c|c|c|c|}
\hline Item & Category & Frequency & Percentage \\
\hline \multirow[t]{2}{*}{ Gender } & Male & 55 & 78.6 \\
\hline & Female & 15 & 21.4 \\
\hline \multirow[t]{5}{*}{ Age } & $21-30$ years old & 9 & 12.9 \\
\hline & $31-40$ years old & 27 & 38.6 \\
\hline & $41-50$ years old & 28 & 40.0 \\
\hline & $51-60$ years old & 3 & 4.3 \\
\hline & Above 60 years old & 3 & 4.3 \\
\hline Race & Malay & 70 & 100.0 \\
\hline \multirow[t]{2}{*}{ Status } & Single & 10 & 14.3 \\
\hline & Married & 60 & 85.7 \\
\hline \multirow[t]{3}{*}{ Education } & SPM/STAM/HSL & 25 & 35.7 \\
\hline & Certificate/Diploma & 20 & 28.6 \\
\hline & Degree & 25 & 35.7 \\
\hline \multirow{2}{*}{$\begin{array}{l}\text { Was working before starting the } \\
\text { business }\end{array}$} & Working & 58 & 82.9 \\
\hline & Not working & 12 & 17.1 \\
\hline \multirow[t]{10}{*}{ Age when starting the business } & Below 31 years old & 14 & 20 \\
\hline & $31-40$ years old & 22 & 31.4 \\
\hline & $41-50$ years old & 30 & 42.9 \\
\hline & $51-60$ years old & 4 & 5.7 \\
\hline & $\begin{array}{l}\text { Agro-based } \\
\text { agriculture }\end{array}$ & 9 & 12.9 \\
\hline & Retail & 4 & 5.7 \\
\hline & Services & 3 & 4.3 \\
\hline & Restaurant & 6 & 8.6 \\
\hline & $\begin{array}{l}\text { Others: } \\
\text { Food and beverages }\end{array}$ & 43 & 61.4 \\
\hline & Clothing \& fragrances & 5 & 7.1 \\
\hline \multirow[t]{2}{*}{ Business status/ownership } & Sole proprietorship & 61 & 87.1 \\
\hline & Partnership & 9 & 12.9 \\
\hline \multirow[t]{2}{*}{ Number of employess } & 1-3 people & 67 & 95.7 \\
\hline & 4-6 people & 3 & 4.3 \\
\hline \multirow{2}{*}{$\begin{array}{l}\text { Year of the business start } \\
\text { operating }\end{array}$} & 2015 & 24 & 34.3 \\
\hline & 2016 & 46 & 65.7 \\
\hline \multirow[t]{3}{*}{ Sources of Finance } & Personal Savings & 49 & 70.0 \\
\hline & Intra-family loans & 6 & 8.6 \\
\hline & Institutional loans & 15 & 21.4 \\
\hline \multirow[t]{2}{*}{$\begin{array}{l}\text { Business net income (per } \\
\text { month) }\end{array}$} & Below RM1000 & 17 & 24.3 \\
\hline & RM1000-RM2500 & 53 & 75.7 \\
\hline \multirow[t]{3}{*}{ Business premises } & Permanent premise & 12 & 17.1 \\
\hline & Market stalls & - & - \\
\hline & Friday Bazaar & 52 & 74.3 \\
\hline
\end{tabular}




$\begin{array}{lll}\text { Mobile franchise } & 6 & 8.6 \\ \text { (moving vehicles) }\end{array}$

Table 2 shows the finding of the mean and standard deviation for the nine independent variables in this study. The finding shows that the teamwork factor has the highest mean value which is 4.2667 and a standard deviation of 0.32896 . Meanwhile, the lowest mean value is on the ICT skills factor which recorded a mean value of 3.5510 and standard deviation of 0.73017 , however, it is still at a moderate level.

Table 2: The analysis of mean and standard deviation of the nine critical success factors.

\begin{tabular}{lcc}
\hline $\begin{array}{l}\text { Critical Success Factors of Entrepreneurial } \\
\text { Practice }\end{array}$ & Mean & $\begin{array}{c}\text { Standard } \\
\text { Deviation }\end{array}$ \\
\hline Financial Management & 3.9486 & .51717 \\
Marketing Management & 4.1524 & .45994 \\
Strategic Planning & 4.0095 & .32463 \\
ICT Skills & 3.5510 & .73017 \\
Communications & 4.2464 & .37468 \\
Teamwork & 4.2667 & .32896 \\
Network & 3.9619 & .44970 \\
Training and Education & 3.7200 & .50665 \\
Entrepreneurial Orientation & 4.1469 & .38684 \\
\hline
\end{tabular}

Table 3 presents the correlation analysis or the relationship between the critical success factors of entrepreneurial practice and business performance of entrepreneurs in Petaling District mosques, Selangor. The finding was interpreted to answer the second question in this study which is 'Is there a relationship between the critical success factors of entrepreneurial practice and business performance of entrepreneurs in the mosque area at Petaling District, Selangor?' and support the hypotheses of the study tested.

Table 3: The Interpretation of the Relationship Between Critical Success Factors and Business Permance.

Dependent Variables of Business Performance.

\begin{tabular}{lllll}
\hline Independent Variables & Sig Value $(p) \begin{array}{l}\text { Correlation } \\
\text { Value }(r)\end{array}$ & $\begin{array}{l}\text { Correlation } \\
\text { Interpretation }\end{array}$ & Ha Status \\
\hline Financial Management & .413 & .099 & Very weak & Rejected \\
Marketing Management & .000 & .671 & Strong & Fail to Reject \\
Strategic Planning & .000 & .740 & Strong & Fail to Reject \\
ICT Skills & .000 & .547 & Moderate & Fail to Reject \\
Communications & .000 & .571 & Moderate & Fail to Reject \\
Teamwork & .577 & .072 & Very weak & Rejected \\
Network & .000 & .705 & Strong & Fail to Reject \\
Training and Education & .000 & .733 & Strong & Fail to Reject \\
Entrepreneurial & .000 & .655 & Strong & Fail to Reject \\
Orientation & & & &
\end{tabular}


Next, multiple regression analysis was conducted to answer the third question, 'What are the critical success factors that greatly influence the business performance of entrepreneurs who operate their business in the mosque area at Petaling District, Selangor?'. The analysis was also performed to measure the validity of the alternative hypotheses from $\mathrm{Ha} 10$ to $\mathrm{Ha} 18$.

Table 4: ANOVA Analysis

\begin{tabular}{lllllll}
\hline Model & & Sum of Squares & $\mathrm{df}$ & $\begin{array}{l}\text { Mean } \\
\text { Square }\end{array}$ & $\mathrm{F}$ & Sig. \\
\hline 1 & Regression & 7.689 & 9 & .854 & 21.078 & $.000^{\mathrm{b}}$ \\
& Residual & 2.432 & 60 & .041 & & \\
& Total & 10.121 & 69 & & &
\end{tabular}

\footnotetext{
A.Dependent Variables: Performance

B.Predictors: (Constants), Entrepreneurial Orientation, Financial management, ICT skills, Teamwork, Communications, Strategic Planning, Training and Education, Marketing management, Network.
}

Table 4 shows the significant value of the F-test is at the value of $(0.000<0.050)$. This further shows that all nine critical success factors influence the dependent variable which is business performance or as a significant means. Moreover, it can also be seen that there are higher percentage values that show the influence of the nine critical success factors on business performance. These data are presented in the model summary in Table 5 below.

Table 5: Multiple regression analysis of critical success factors.

\begin{tabular}{lllll}
\hline Model $\mathrm{R}$ & R-Square & Adjusted R-Square & $\begin{array}{l}\text { Standard Error of } \\
\text { the Estimate }\end{array}$ \\
\hline 1 & $.872^{\mathrm{a}}$ & .760 & .724 & .20133
\end{tabular}

a. Predictors: (constants), Entrepreneurial Orientation, Financial Management, ICT skills, Teamwork, Communications, Strategic Planning, Training and Education, Marketing Management, Network.

From Table 5, it can be seen that the value of R-Squared is .760 which means that a combination of nine independent variables can create a variation in the business performance of entrepreneurs in the Petaling District mosques, Selangor by 76 percent.

Generally, the nine critical success factors namely, financial management, marketing management, ICT skills, teamwork, communication skills, strategic planning, training and education, network, and entrepreneurial orientation are known to have a mutual influence over business performance. However, to provide an answer for the third question, 'What are the critical success factors that greatly influence the business performance of entrepreneurs in mosques area at Petaling District, Selangor?', the researcher has analyzed multiple regression data by looking at significant values and t-values as shown in Table 6 below. 
Table 6: The Coefficient values of each critical success factors.

\begin{tabular}{lccccc}
\hline \multicolumn{5}{c}{ Unstanderdized coefficients } & \multicolumn{3}{c}{ Standardized coefficients } \\
\cline { 2 - 4 } & B & Stror & & \\
\hline Model & & & & & \\
(Constant) & -.770 & .527 & & -1.462 & .149 \\
Financial Management & -.054 & .066 & -.073 & -.826 & .412 \\
Marketing Management & .018 & .103 & .021 & .172 & .864 \\
Strategic Planning & .545 & .141 & .462 & 3.868 & .000 \\
Ict Skills & .049 & .059 & .092 & .819 & .416 \\
Communications & .125 & .126 & .123 & .992 & .325 \\
Teamwork & .111 & .095 & .095 & 1.159 & .251 \\
Network & -.145 & .125 & -.170 & -1.159 & .251 \\
Training and Education & .253 & .085 & .335 & 2.970 & .004 \\
Entrepreneurial & .235 & .105 & .237 & 2.229 & .030 \\
Orientation & & & & & \\
\hline
\end{tabular}

Dependent Variables: Performance

Based on Table 6 above, the t-value is used to determine each of the critical success factors that affect the business performance in the Petaling District mosques, Selangor. These findings were also used to answer the $\mathrm{Ha} 10$ to $\mathrm{Ha} 18$ hypotheses. Referring to the above table, it can also be concluded that three factors influenced business performance namely, strategic planning factor $(0.000<0.05)$, training and education factors $(0.004<0.05)$, and entrepreneurial orientation factor $(0.030<0.05)$. The finding also shows that the value of the coefficient for the strategic planning factor is 0.545 which means that a one per cent increase in strategic planning will increase business performance by 54.5 percent. On the other hand, the value of the coefficient for the training and education factor shows 0.235 which leads to a one percent increase in training and education will also increase business performance by 25.3 percent. And, the last coefficient value is the entrepreneurial orientation with a value of 0.235 which means that each one percent increase in the entrepreneurial orientation will also improve business performance by 23.5 percent. 
Table 7: Alternative Hypotheses Status.

\begin{tabular}{|c|c|c|}
\hline & Alternative Hypotheses & Ha Status \\
\hline Ha10 & $\begin{array}{l}\text { Financial management factor affect the business } \\
\text { performance of entrepreneurs in the Petaling District } \\
\text { mosques, Selangor. }\end{array}$ & Rejected \\
\hline Ha11 & $\begin{array}{l}\text { Marketing management factor influence the business } \\
\text { performance of entrepreneurs in the Petaling District } \\
\text { mosques, Selangor. }\end{array}$ & Rejected \\
\hline $\mathrm{Ha} 12$ & $\begin{array}{l}\text { Strategic planning factor affect the business } \\
\text { performance of entrepreneurs in the Petaling District } \\
\text { mosques, Selangor. }\end{array}$ & Failed to Reject \\
\hline Ha13 & $\begin{array}{l}\text { ICT management factor affect the business } \\
\text { performance of entrepreneurs in the Petaling District } \\
\text { mosques, Selangor. }\end{array}$ & Rejected \\
\hline Ha14 & $\begin{array}{l}\text { Communication factor affect the business } \\
\text { performance of entrepreneurs in the Petaling District } \\
\text { mosques, Selangor. }\end{array}$ & Rejected \\
\hline Ha15 & $\begin{array}{l}\text { Teamwork factor influence the business performance } \\
\text { of entrepreneurs in the Petaling District mosques, } \\
\text { Selangor. }\end{array}$ & Rejected \\
\hline Ha16 & $\begin{array}{l}\text { Network factor affect the business performance of } \\
\text { entrepreneurs in the Petaling District mosques, } \\
\text { Selangor. }\end{array}$ & Rejected \\
\hline Ha17 & $\begin{array}{l}\text { Training and education factor influence the business } \\
\text { performance of entrepreneurs in the Petaling District } \\
\text { mosques, Selangor. }\end{array}$ & Failed to Reject \\
\hline $\mathrm{Ha} 18$ & $\begin{array}{l}\text { Entrepreneurial orientation factor influence the } \\
\text { business performance of entrepreneurs in the } \\
\text { Petaling District mosques, Selangor. }\end{array}$ & Failed to Reject \\
\hline
\end{tabular}

\section{Discussion and Conclusion}

i. What is the level of critical success factors (CSF) for entrepreneurial practices which had been identified in the entrepreneurial business in the Petaling District mosques, Selangor?

The result of the study shows that the highest mean score or value recorded was on the teamwork factor exercised by entrepreneurs in the Petaling District mosques, Selangor.The mean value obtained is 4.2667 and the finding of all items submitted were also at a high level. The four items with a high level of mean value are 'I encourage each of the employee to share the responsibilities that are entrusted to them', 'I encourage each of the employees to deal with conflict in a constructive manner', 'I ensure that each of the employees has the same opportunity to voice their views/ideas/comments in business management', and 'I motivate all employees to be responsible and committed to the task assigned in the business'. Based on these items the researcher can conclude that each of the employees fully cooperates in the team. This is because the entrepreneur or business owner cares about their employee issues, gives freedom to the employee to speak out and skillfully deal with problems faced in the business. 
ii. Is there a relationship between critical success factors (CSF) and the business performance of entrepreneurs in the Petaling District mosques, Selangor?

The result shows that five critical success factors have a significant relationship with the business performance namely, marketing management factor, strategic planning factor, networf factor, training and education factor, and entrepreneurial orientation factor. Meanwhile, two factors that are at a moderate level namely, the ICT skills factor and communication factor which, illustrated that these factors have a moderately good significant relationship with business performance. And, the other two remaining factors indicate a very weak relationship or can be considered to have no significant relationship towards business performance. Based on these findings, the researcher has interpreted the alternative hypotheses of the study from $\mathrm{Ha} 1$ to $\mathrm{Ha} 9$ in which the critical success factors have a significant relationship with business performance. The result had shown that seven research hypotheses had failed to be rejected because of the critical success factors that are significantly related to the business performance of entrepreneurs in the mosques at Petaling District, Selangor. The other two hypotheses proposed were rejected because they did not show any significant relationship between the critical success factors and business performance.

iii. What are the critical success factors (CSF) that greatly influence the business performance of entrepreneurs who operated their business in the Petaling District mosques, Selangor?

Overall, the findings of the study show that all the critical success factors affect the business performance at the value of $R^{2}=0.760$. However, this value will not show the same consistency if each of the critical success factors to be analyzed one by one. This is due to the data processing that is being made in one thorough process and does not focused on every single factor. The results of analysis on each critical success factor found that three factors influence the business performance namely, strategic planning factor, training and education factors, and entrepreneurial orientation factor. These three factors display a much lower significant value than the significant value of 0.05 that had been determined. Therefore, these findings also answer and confirm the hypotheses in which, hypotheses $\mathrm{Ha} 12$, Ha17 and $\mathrm{Ha} 18$ are failed to be rejected while the remaining hypotheses were rejected because it does not affect the business performance of entrepreneurs.

Hence, few suggestions can be made for the improvement of this study. Firstly, the researcher suggested that future researchers could do a broader study that does not focus only on the Petaling District mosques, Selangor but also extend it to all states in Malaysia. This is because based on the observation, entrepreneurship in the mosque area has also been widely established in other states. In addition, the research method can also be changed from using a quantitative method to a qualitative method. This is due to the difficulty faced by the researcher to collect all the distributed questionnaires. For that reason, the researcher proposed that the interview method is also appropriate to collect the data because the information obtained is more transparent and detailed.

In conclusion, all three research questions were answered and the results had shown that the seven critical success factors studied had a significant relationship with business performance while two factors show a very weak relationship and were considered as not directly related to business performance. On the other hand, three critical success factors of entrepreneurial practices namely, strategic planning factor, training and education factors, 
and entrepreneurial orientation factor were interpreted as to influence business performance. Hence, the tested research hypotheses were positive and accepted.

\section{Corresponding Author}

Nurul Aini Ilmiah Munzir

Universiti Pendidikan Sultan Idris, Malaysia

Email: Nurulainiilmiah@yahoo.com

\section{References}

Ab Ghani, A. M., \& Sarif, S. (2005). The application of entrepreneurial culture in Muslim society. National Level Islamic Entrepreneurship Seminar 2005, Academy of Islamic Studies, University of Malaya, Kuala Lumpur. Retrieved from http://eprints.um.edu.my/146/1/01_-_Penerapan_Budaya.pdf.

Ab Wahab, N. Y., \& Ahmad, S. (2017). The Relationship Between ICT Use and SME Business Performance in Malaysia. Journal of Global Business and Social Entrepreneurship (GBSE) 1(3), 218-226.

Abdul Manaf, A., Omar, N. H., \& Lee K.Y. (2012). Critical Factors of Entrepreneurial Success in Business. Journal of Social Sciences and Humanities, 7 (1), 34-45.

Abdul Talib, H. H., Ali, M. K. A., \& Idris, F. (2013). The Relationship of Quality Management Practices on the Organizational Performance of Food Processing Industry SMEs in Malaysia. Journal of Technology (Social Science), 61 (1), 1-10. http://eprints.utm.my/id/eprint/33656/1/JT_SS_61mac2013_01.pdf

Abdullah, M. A., Kedah, Z., \& Anwar, M. A. (2015). The effect of Islamic entrepreneurial mind programming on entrepreneurial performance through entrepreneurial motivation. International journal of Business and Globalization, 15(3), 294-312.

Ahmad, S., \& Abdul Ghani, A. (2013). Entrepreneurial Orientation and Business Performance: The Moderating Influence of Transformational Leadership Styles. Journal of Management 37, 115-123. http://journalarticle.ukm.my/6963/1/3633-8096-1-PB.pdf

Ali, N. A., \& Mahat, F. (2009). The Capability Of Medium, Small And Micro Industry Financing Institutions In Producing And Empowering Viable Small Entrepreneurs Towards A New More Effective Approach. Islamic Economic Congress 3, 1-13.

Aris, H. A., \& Musa, N. S. (2014). Management of Tabung Masjid Towards the Economic Development of the Local Community. Proceedings of the International Conference on Mosques, Zakat and Wakaf (IMAF 2014), 180-188.

Basir, S. A., Che Pa, B., \& Sulong, R. H. (2009). Principles of Quality Towards Producing Successful Muslim Entrepreneurs. Journal of Syariah, 17 (2), 327-352. https://ejournal.um.edu.my/index.php/JS/article/view/22738/11283.

Delarue, A., Van Hootegem, G., Procter, S., \& Burridge, M. (2008). Teamwork and Organizational Performance: A Study -Based Research Study. International Journal of Management Review, 10 (2), 127-148. http://doi.org/10.1111/j.14682370.2007.00227.x

Farinda, A. G., Kamarulzaman, Y., Abdullah, A., \& Ahmad, S. Z. (2009). Developing Business Networks: A Proposed Framework for UKM Malaysia. International Review of Business Research Papers, 5 (1), 151-160.

Hamed, A. B. (2006). Entrepreneurship and Small Business Management. Sintok: Universiti Utara Malaysia Publishers. 
Harom, N. A. (2014). Factors Affecting the Performance of a Small-Scale Business. Scientific Training. Sultan Idris Education University.

https://www.researchgate.net/publication/242083862_Building_Business_Networkin g_A_Proposed_Framework_for_Malaysian_SMEs

Hunter, M. (2014). Entrepreneurship as a Means of Creating an Islamic Economy. Economics, Management, and Financial Markets, 9 (1), 75-100.

http://ezproxy.usim.edu.my://2102/pqcentral/docview/1520014352/fulltextPDF/949 119ADD7214BAFPQ/18?accountid=33993

Husen, T., Ahmad, H., \& Noor, M. N. A. (2010). The driving performance and continued competitiveness of small and medium enterprises in the context of a dynamic market environment. Proceedings of Perkem V, Vol. 2, 114-120.

Idris, N. A., \& Shahadan, F. (2009). Quality System Analysis in the Context of Status and Performance: A Case Study of Agro-Based Small and Medium Industries. Proceedings of PERKEM iv, Vol. 2, 2-4.

Isaac, M. S., \& Zainorazlin, M. N. (2017). Factors of Teamwork and Its Influence on Performance. Journal of the Humanities, 1 (2), 42-52.

Johnson, M. (2013). Critical success factors for B2B e-markets: a strategic suitability perspective, 31 (6), 698-727. Retrieved from http://doi.org/10.1108/MIP-10-2013-001

Phihie, L. K. A., \& Elias, H. (2004). The Ability of Bumiputera Entrepreneurs to Implement Entrepreneurial Skills: Pertanika Journal Social Science \& Humanities, 12 (1): 6170.http://psasir.upm.edu.my/id/eprint/3454/1/Keangga_Usahawan_Bumiputera_ Melaksanaan_Kemahiran.pdf

Deris, M. S. N. B., \& Noor, M. A. (2015). Comparison of Halal Industry Competitiveness In Malaysia And Kosher In Israel. Proceedings of Conference on Malaysian Islamic Economics and Finance (Cmief 2015), (pp. 23-32)

Desa, M. S., \& Sarif, S. (2013). Mosques and buying and selling activities: their prospects and challenges. In International Convention on Islamic Management 2013 (pp. 1-12). https://www.academia.edu/5913804/MASJID_DAN_AKTIVITI_JUAL_BELI_PROSPEK_D AN_CABARANNYA

Nasir, M. A. (2014). Performance of Islamic Entrepreneurs in the Production of Halal Products in Kluang District, Johor. Scientific Training. Tanjong Malim: Sultan Idris University of Education.

Yusoff, M. Y., \& Sulaiman, M. A. (2004). A study on community feedback on the activities of State Mosques in Peninsular Malaysia. Journal of Usuluddin, 20, 201-222.

Noorzeli, M. N. (2014). The Relationship between Business Performance and HRV Biofeedback Profile of Amanah Ikhtiar Malaysia Entrepreneurs. Academic 84 (1 \& 2) 45-56. http://journalarticle.ukm.my/8282/1/7886-20514-1-PB.pdf

Mohamad, A. (2006). Relationship Between Franchisor-Franchisee in Kuala Terengganu, Terengganu. Tanjong malim: Sultan Idris University of Education.

Mohamad, M. H. (2009). Toyyiban's Halal Demands Can Empower the Ummah's Economy. Utusan Malaysia. http://www.ikim.gov.my/index.php/2009/03/20/tuntutan-halalantoyyiban-boleh-memperkasakan-ekonomi-ummah/

Nor, M. N. A. (2009). 3 Spi Students' Perceptions of the Role of the Mosque from the Perspective of Education in the Muslim Community. http://eprints.utm.my/id/eprint/10438/1/PERSEPSI_PELAJAR_3_SPI_TERHADAP_PERA NAN_MASJID_DARI_SUDUT.pdf 
Nadzri, S., Shamsudin, M. S., \& Sabri, M. F. (2014). Factors Contributing to The Success and Failure Of Bumiputera Small And Medium Enterprises (SMEs) In Malaysia. Eproceedings of the Conference on Management and Muamalah (pp. 978-983). Selangor International Islamic University College. May 26-27.

Nasharudin, N., \& Harun, H. (2010). Entrepreneurial Career Aspirations Among Students of Public Institutions of Higher Learning. Malaysian Journal of Education, 35 (1), 11-17. http://doi.org/10.1177/1069072710385547

Mustapen, N. R. (2012). Factors Influencing Business Performance Among Entrepreneurs One District One Industry (SDSI) in Malaysia. Undergraduate Dissertation. Sultan Idris Education University.

Omar, F. I., A. Rahim, S., \& Salman, A. (2017). Internet Use Among Women Entrepreneurs: Access, Skills and Motivation. Journal of Communication Malaysian Journal of Communication, 33 (3), 21-36. http://journalarticle.ukm.my/11411/1/17952-58941-3PB.pdf

Osman, J. (2014). Management practices and business performance among retail consumers in Hulu Perak District. Scientific Training. Sultan Idris Education University.

Quan, V. Le, \& Raven, P. V. (2015). Woman Entrepreneurship in Rural Vietnam: Success and Motivational Factors, 49 (2), 57-76.

Rahim, M. S., Abd. Khalid, A. Z., Abdullah, S., Abdullah, S., Ahmad, S., Zakaria, N., Adon, I., Mohamad, A., \& Poespowidjojo, D. A. L. (2017). Fundamentals of Entrepreneurship: Towards Strengthening the Mind and Entrepreneurial Skills, Kedah: UUM Press.

Rajuddin, M. R., \& Saleh, M. D. (2008). Level Of Effectiveness Of Efforts Carried Out By The Residents Of Kampung Segamat, Johor To Increase Their Source Of Income Through Agriculture. Retrieved from https://core.ac.uk/reader/11786070

Ramli, A., Husin, M. F., \& Shakir, A. K. (2013). The Impact of Business Relationships on Organizational Performance: A Study on Relationships and the Influence of Business Relationships on Manufacturer's Warehouse Operational Performance in Peninsular Malaysia., 71-80. http://repo.uum.edu.my/16305/1/9.pdf

Tunggak, B., Salamon, H., \& Abu, B. (2011). The Need for Continuing Training and Education Towards the Development of Muslim Entrepreneurs Based on Islamic Values in Malaysia. Journal of Technology, 55, 121-144.

Wahab, A., Idris, A., \& Abdul Wahab, D. (2020). The Role of Strategic Management in Growth of Small and Medium Enterprises (Smes) In Malaysia. Journal of Sciences and Humanities, 17 (1), 108-124.

https://ejournal.ukm.my/ebangi/article/view/37705/10231

Yogeswaran, V. (2015). The Influence of Leadership Style, Management Competence and Entrepreneurial Orientation on the Performance of Small and Medium Enterprises (SMEs) of Indian Entrepreneurs in Malaysia. Doctoral Dissertation, Sultan Idris University of Education.

Yusof, A. A. (2010). Entrepreneurship and Strengthening Business Partner Networks. Sintok: Penerbit Universiti Utara Malaysia 